\title{
Systems analysis of the transcriptional response of human ileocecal epithelial cells to Clostridium difficile toxins and effects on cell cycle control
}

\author{
Kevin M D'Auria', Gina M Donato², Mary C Gray², Glynis L Kolling², Cirle A Warren², Lauren M Cave², \\ Michael D Solga ${ }^{3}$, Joanne A Lannigan ${ }^{3}$, Jason A Papin ${ }^{1 *}$ and Erik L Hewlett ${ }^{2^{*}+}$
}

\begin{abstract}
Background: Toxins A and B (TcdA and TcdB) are Clostridium difficile's principal virulence factors, yet the pathways by which they lead to inflammation and severe diarrhea remain unclear. Also, the relative role of either toxin during infection and the differences in their effects across cell lines is still poorly understood. To better understand their effects in a susceptible cell line, we analyzed the transciptome-wide gene expression response of human ileocecal epithelial cells (HCT-8) after 2, 6, and $24 \mathrm{hr}$ of toxin exposure.

Results: We show that toxins elicit very similar changes in the gene expression of HCT-8 cells, with the TcdB response occurring sooner. The high similarity suggests differences between toxins are due to events beyond transcription of a single cell-type and that their relative potencies during infection may depend on differential effects across cell types within the intestine. We next performed an enrichment analysis to determine biological functions associated with changes in transcription. Differentially expressed genes were associated with response to external stimuli and apoptotic mechanisms and, at $24 \mathrm{hr}$, were predominately associated with cell-cycle control and DNA replication. To validate our systems approach, we subsequently verified a novel $G_{1} / S$ and known $G_{2} / M$ cell-cycle block and increased apoptosis as predicted from our enrichment analysis.
\end{abstract}

Conclusions: This study shows a successful example of a workflow deriving novel biological insight from transcriptome-wide gene expression. Importantly, we do not find any significant difference between TcdA and $T c d B$ besides potency or kinetics. The role of each toxin in the inhibition of cell growth and proliferation, an important function of cells in the intestinal epithelium, is characterized.

Keywords: Clostridium difficile, Toxin A, Toxin B, gene expression, epithelial cell, cell-cycle

\section{Background}

C. difficile, a Gram-positive, spore-forming anaerobe, colonizes the human gut and causes infections leading to pseudomembranous colitis. This opportunistic pathogen flourishes in antibiotic-treated and immunocompromised patients and is frequently spread in hospitals, although community-acquired Clostridium difficile infection (CDI) cases have also increased [1]. The

\footnotetext{
* Correspondence: papin@virginia.edu; eh2v@virginia.edu

+ Contributed equally

'Department of Biomedical Engineering, University of Virginia, Charlottesville, Virginia, 22908, USA

${ }^{2}$ Division of Infectious Diseases and International Health, Department of

Medicine, University of Virginia, Charlottesville, Virginia, 22908, USA

Full list of author information is available at the end of the article
}

emergence of hypervirulent strains that possess more robust toxin production and increased sporulation has been correlated with outbreaks across Europe and North America [2]. In most areas, the number of cases has increased in the past decade. The number of patients hospitalized in the US with CDI doubled to approximately 250,000 /year (from year 2000 to 2003) and fatalities increased at a similar rate [3]. The US healthcare costs for CDI are estimated to be over $\$ 1$ billion/year [4]. As TcdA and TcdB appear to be responsible for many of the clinical manifestations of CDI, understanding the intracellular and systemic effects of each toxin is critical to developing and improving strategies for treatment and prevention.

\section{() Biomed Central}


In light of the multiple events and pathways involved in the development of CDI, we chose to examine the toxins' effects from a systems perspective, focusing on epithelial cells in vitro. Both TcdA and TcdB bind to cells [5], enter an endosome by clathrin-mediated endocytosis [6], translocate and then cleave their catalytic domain into the cytosol which glucosylates and so inactivates Rho family proteins [7]. The disruption of these crucial signaling regulators begins to explain cytotoxic effects such as deregulation of the cytoskeleton and the breakdown of the epithelial barrier [8]. However, other processes are likely affected by the trafficking and processing of these toxins. In addition, secondary effects of Rho glucosylation in relation to pathologies of CDI have not been fully elucidated.

We therefore investigated the transcriptional profile of HCT-8 [9] cells treated with TcdA or TcdB and identified pathways and cellular functions associated with differentially expressed genes. With respect to toxins, in vitro analyses of gene expression in host cells have been performed with type A botulinum neurotoxin, lethal toxin [10] and edema toxin [11] from Bacillus anthracis, pertussis toxin [12], Shiga toxin type 1 [13], and several others. Such studies provide lists of differentially expressed genes or classes of genes that serve as a resource for the generation of new hypotheses. In this regard, we used bioinformatics analyses to identify cellular functions altered by TcdA and $\mathrm{TcdB}$ that are relevant to pathogenicity. The correct identification of the majority of functions found to be affected in previous research regarding $\mathrm{Tcd} A$ and $\mathrm{TcdB}$ confirmed our analysis and experimental design, and experiments reported herein validated changes in cell function that were suggested by altered gene expression.

Among the genes that TcdA and TcdB affect, many are involved in the regulation of the cell cycle and induction of apoptosis. Bacterial factors such as cytotoxic necrotizing factor and cytolethal distending toxins that disrupt normal cell cycle progression have been described as "cyclomodulins" [14]. In addition to effects of TcdA and TcdB on cells in the $G_{2} / M$ phase which have been described previously [15-18], we found that TcdA and TcdB affect expression of cyclins and cyclin-dependent kinase (CDK) inhibitors controlling the $\mathrm{G}_{1}-\mathrm{S}$ transition. Our experiments establish that alterations of cell cycle implicated in our analysis of gene expression do, in fact, occur in toxin-treated cells. In addition to effects on cell cycle, we also present the other cellular functions associated with differentially expressed genes, some of which enable novel hypotheses on the cellular activity and function of these toxins.

\section{Methods}

\section{Cell Culture}

HCT-8 cells were cultured in RPMI-1640 supplemented with $10 \%$ heat-inactivated fetal bovine serum (Gibco) and $1 \mathrm{mM}$ sodium pyruvate (Gibco). The cultures were maintained at $37^{\circ} \mathrm{C} / 5 \% \mathrm{CO}_{2}$ up to passage 35 . Toxin $\mathrm{A}$ and Toxin B, isolated from strain VPI-10643, were a generous gift from David Lyerly (TECHLAB Inc., Blacksburg, VA).

\section{Microarrays}

HCT-8 cells $\left(5 \times 10^{6} /\right.$ flask $)$ were grown overnight at $37^{\circ}$ $\mathrm{C} / 5 \% \mathrm{CO}_{2}$. Media were replaced with $2.5 \mathrm{ml}$ fresh media and toxin was added $(100 \mathrm{ng} / \mathrm{ml})$. At the end of the indicated incubation period, cells were washed with $5 \mathrm{ml}$ PBS (Sigma) and total RNA was isolated using the QIAshredder and RNeasy mini kits (Qiagen), according to the manufacturer's instructions. An RNase inhibitor was added (RNasin, Promega) and samples were stored at $-80^{\circ} \mathrm{C}$. RNA integrity was assessed using an Agilent 2100 BioAnalyzer prior to cDNA synthesis and RNA labeling using either the 3' IVT expression or one-cycle target labeling methods (Affymetrix). Biotin-labeled RNA was hybridized to Human Genome U133 Plus 2.0 chips, washed, stained and scanned using a GeneChip System 3000 7G (Affymetrix). Data from three independent microarray experiments were deposited into the NCBI Gene Expression Omnibus repository (GSE29008).

Microarray signal intensities were normalized using the gcrma package [19]. Treatment and control groups were contrasted with linear models; a Benjamini-Hochberg correction was applied across all the probes and the nestedF method within the limma software package was used for multiple testing across all contrasts [20,21]. The Gene Ontology (GO) annotation database was used to map gene symbols to GO categories [22]. A gene symbol was considered differentially expressed if at least one of the probe sets annotated to it was significant. A probe set was considered significant if the $p<0.1$ and the magnitude of the fold change was above 1.5. Enriched GO categories were identified with the topGO package using Fisher's exact test to calculate p-values and the elim algorithm [23].

\section{Flow Cytometry}

HCT-8 cells were grown overnight to $50 \%$ confluence, media were removed and replaced with fresh media, and toxin was added at the concentrations denoted in the text and figures. At $24 \mathrm{~h}$ and $48 \mathrm{~h}$, non-adherent cells were removed and saved on ice. Adherent cells were treated with $1 \mathrm{~mL}$ of $0.25 \%$ trypsin and $1 \mathrm{~mL}$ of Accutase with EDTA for $30 \mathrm{~min}$ at room temperature and joined with the non-adherent cells in $5 \mathrm{~mL}$ PBS. After centrifugation, resuspension for counting cells, and another round of centrifugation, the dissociated cells were resuspended to $2 \times 10^{6}$ cells $/ \mathrm{mL}$ and $0.5 \mathrm{~mL}$ was added to $5 \mathrm{~mL}$ of $70 \%$ ice-cold ethanol for fixation. Afterward, the fixed cells were resuspended in $5 \mathrm{ml}$ PBS 
with 2\% Bovine Serum Albumin and then resuspended and incubated for $30 \mathrm{~min}$ in a solution to stain DNA (PBS with 10\% Triton X-100, 2\% DNasefree RNase, $0.02 \%$ propidium iodide(PI)). Single-cell fluorescence was measured with a Becton Dickinson FACSCalibur flow cytometer. The proportion of cells in each stage of the cell cycle was calculated using ModFit cell cycle analyzer. The $24 \mathrm{~h}$-samples were imaged with an Amnis Imagestream imaging flow cytometer, which photographs the bright field and fluorescent channels from every cell individually [24]. Using Amnis software, a bivariate gate-based on the contrast of the brightfield image and the area of nuclear stain-differentiated apoptotic and non-apoptotic cells [25]. All other image features were taken from the Amnis software.

\section{Results}

\section{Transcriptional Responses}

Overall, the changes in gene expression are consistent as time progresses, but the number of differentially expressed genes increases (Figure 1A). Specifically, at 2 $\mathrm{h}$ and $6 \mathrm{~h}$, there are 4 and 134 probe sets differentially expressed (relative to control) for TcdA and 57 and 294 for $\mathrm{TcdB}$, respectively (Figure $1 \mathrm{C}$ ). Many more are differentially expressed by $24 \mathrm{~h}-1,155$ and 1,205 in TcdAand TcdB-treated cells, respectively. In order to validate these data, qRT-PCR was performed on 10 representative genes $(r=0.89$ by Pearson correlation; Additional File 1; Additional File 2, Figure S1 A). Since the glucosylation of Rho family proteins occurs within one hour of toxin treatment [26], many of the differentially expressed genes at $24 \mathrm{~h}$ may reflect secondary effects from the initial toxin action or possibly other unknown activities and processing of the toxin.

Though the transcriptional responses to the two toxins are similar overall, a notable difference between the two toxins is that TcdB-induced changes occur more rapidly (Figure 1A). At the later time points, however, the overall transcriptional response induced by TcdA becomes more similar to the TcdB-induced transcriptional changes (see correlations in Figure 1B). Among the most affected genes, immediate early-response genes such as JUN, KLF2, and RHOB are upregulated $2 \mathrm{~h}$ after toxin treatment and remain increased compared to untreated cells through $24 \mathrm{hr}$ (Additional File 2, Figure S1 B). While identification of the most-affected genes provides important insight, focusing on a small subset risks overlooking other toxin effects key to the disease process. We therefore analyzed the expression data in the context of broad functional categories.

\section{Functions associated with differentially expressed genes}

We employed the GO database, which contains extensive annotation of biological functions associated with

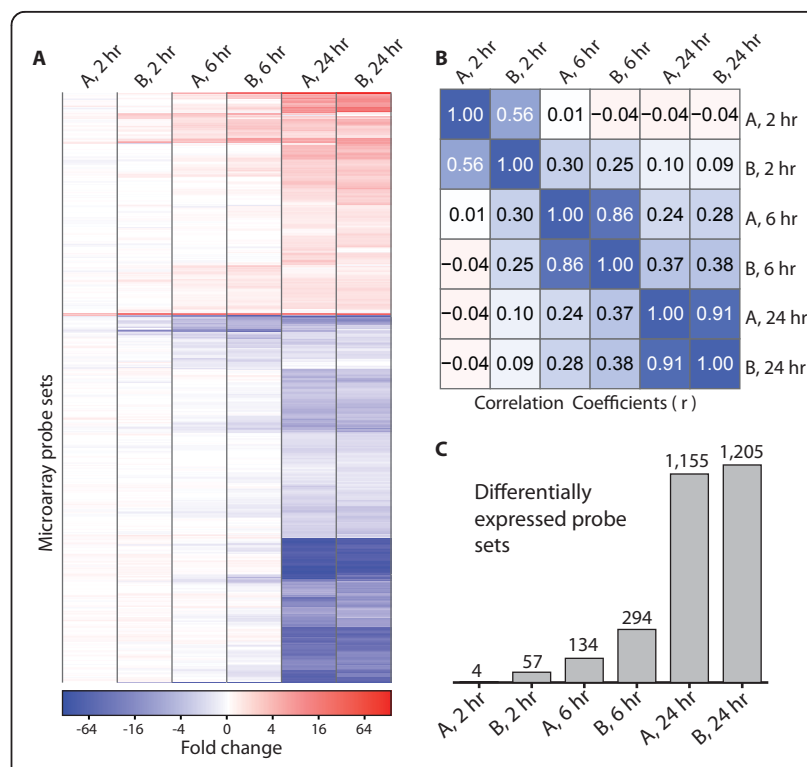

Figure 1 Overall transcriptional response of HCT-8 cells to TcdA and TcdB. A. A heatmap shows the number of differentially expressed probe sets at $2 \mathrm{~h}, 6 \mathrm{~h}$, and $24 \mathrm{~h}$. The color scale represents the fold change (binary log scale) of genes relative to untreated cells at the same time point. "A, 2 hr" indicates the gene expression of cells after $2 \mathrm{~h}$ of TcdA treatment. TcdA and TcdB concentration is $100 \mathrm{ng} / \mathrm{ml}$. B. The correlation of transcriptional profiles between $T c d A$ and $T c d B$ at the indicated time points are displayed in a correlation matrix. The values represent the Pearson correlation coefficient calculated from the fold change of all the probe sets within the microarray. C. The number of differentially expressed genes used to identify enriched GO categories was determined from a linear model (Methods).

specific genes, to identify cellular phenotypes associated with changes in gene expression. The terms in this database are separated into three ontologies: Molecular Functions, Cellular Components, and Biological Processes (detailed descriptions at http://www.geneontology.org). A GO category-here defined as all the genes associated with a single GO term-with a proportion of differentially expressed genes greater than would be expected by chance is considered overrepresented or enriched (Methods). While some enriched categories might have been anticipated, others provide novel insights. Within the Biological Processes ontology, the most significantly enriched categories at 2 and $6 \mathrm{hr}$ are listed in Figure 2A. Within the Cellular Component ontology, the mitochondrial outer membrane and the apical junction complex category are enriched most significantly at $6 \mathrm{~h}$ (Additional File 3, Figure S2 A). Interestingly, many of the functions related to the enriched categories have been linked with toxin treatment in previous work. One or both of the toxins induce activation of caspases [17,27-29], damage mitochondria and cause the release of cytochrome c [30,31], increase oxygen radicals and 
expression of cytokines [32-34], alter MAPK signaling [35-37], and disrupt the organization of tight junctions [8]. Hence, our analysis of gene expression as summarized in Figure 2 is consistent with the previously reported cellular responses to these toxins.

The most significantly enriched categories for each toxin at the later time points are related to cell cycle and DNA replication (Figure 2B). Categories such as telomere maintenance and nucleosome assembly provide more specific connections between the toxins and changes in DNA replication. A more extensive list reveals that several categories related to microtubule organization during cell division are also enriched (Additional File 3; Figure S2 B). By $24 \mathrm{hr}$, there are changes related to virtually all elements of the cell cycle, but those controlling $G_{1}$ and $S$ phases are more significantly affected. Though many of the genes within the enriched categories were not among the most differentially expressed genes, the abundance of differentially expressed genes involved in the same functions provides evidence for toxin effects on control of cell cycle at the $G_{1}$ phase. Cyclins and other proteins necessary for

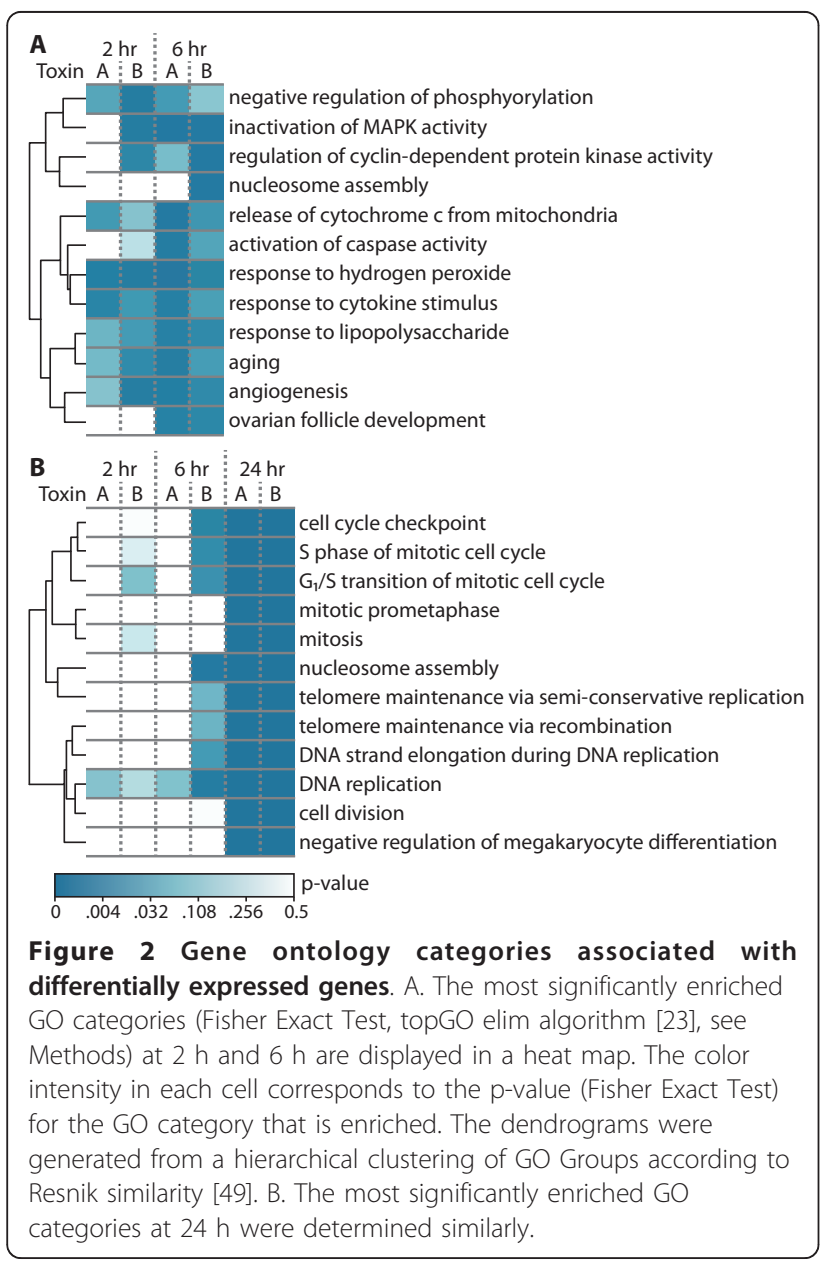

progression from the $G_{1}$ phase into and through the $S$ phase are downregulated (Figure 3A). Cyclin proteins expressed at different points are central in coordinating entry into or exit from different phases. They specifically bind and activate particular CDKs which then phosphorylate downstream targets effecting progression [38]. Inhibitors of cyclin-CDK complexes from the INK4 family (p15, p16, p18, and p19) and Cip/Kip family (p21, p27, and p57) may suppress cyclin-CDK signaling [39]. Expression of many of these and other genes, such as CDC6 and CDC25A that are required for progression from $G_{1}$ to the $S$ phase, is altered by TcdA and TcdB. The decreased expression of $G_{1}$ cyclins along with the increased expression of inhibitors of $\mathrm{G}_{1}$-associated cyclin-CDK complexes suggest altered regulation of the cell cycle specifically in $G_{1}$. We also measured expression of genes and proteins (Additional File 1 Additional File 4) after 6 and $24 \mathrm{hr}$ of treatment with $0.1,1$, and 10 $\mathrm{ng} / \mathrm{ml}$ of TcdA or TcdB in confluent and subconfluent cultures, which confirmed a consistent alteration of cell cycle genes and proteins across a variety of conditions.

\section{Effects of TcdA and TcdB on the Regulation of Cell Cycle}

The functional changes suggested by altered gene and protein expression were then investigated by quantifying the proportion of cells in each phase of the cell cycle before and after toxin treatment. To focus on actively growing cells and avoid the effects of contact inhibition, subconfluent cultures were used. After $24 \mathrm{hr}$ of 0.1 or 1 $\mathrm{ng} / \mathrm{ml} \mathrm{TcdB}$ treatment, the distribution of cells across the cell cycle changes significantly, with only a small increase in the proportion of cells with less than a $G_{0} /$ $\mathrm{G}_{1}$ amount of DNA-cells that are presumably dead or dying (Figure 3B). In agreement with our gene expression analysis, the percentage of $\mathrm{G}_{0} / \mathrm{G}_{1}$ cells increased from $67 \%$ in untreated cells to $91 \%$ and $94 \%$ in cultures treated with $10 \mathrm{ng} / \mathrm{ml} \mathrm{TcdA}$ and $1 \mathrm{ng} / \mathrm{ml} \mathrm{TcdB}$, respectively (Figure 3C). The magnitude of increase in the $\mathrm{G}_{0} /$ $\mathrm{G}_{1}$ proportion is also concentration-dependent. The effect on cell cycle by the combination of TcdA and $\mathrm{TcdB}$ is comparable to those produced by $\mathrm{TcdB}$ alone (Figure 3C), indicating that, with respect to their influence on cell-cycle arrest, the toxins are neither synergistic nor antagonistic. As with gene and protein expression, TcdB is more potent or faster-acting than TcdA. Taken together, these data establish that the toxin-induced alterations in genes associated with cell cycle correlate with a block at the $\mathrm{G}_{1}-\mathrm{S}$ interface. In other studies, a $G_{2} / M$ arrest has been reported in human cell lines treated with different concentrations of TcdA or TcdB [16-18]. This $G_{2} / M$ arrest has been linked with a deregulation of the cell structure resulting in an inability of cells to complete cytokinesis [40]. We therefore investigated the cell cycle effects and 


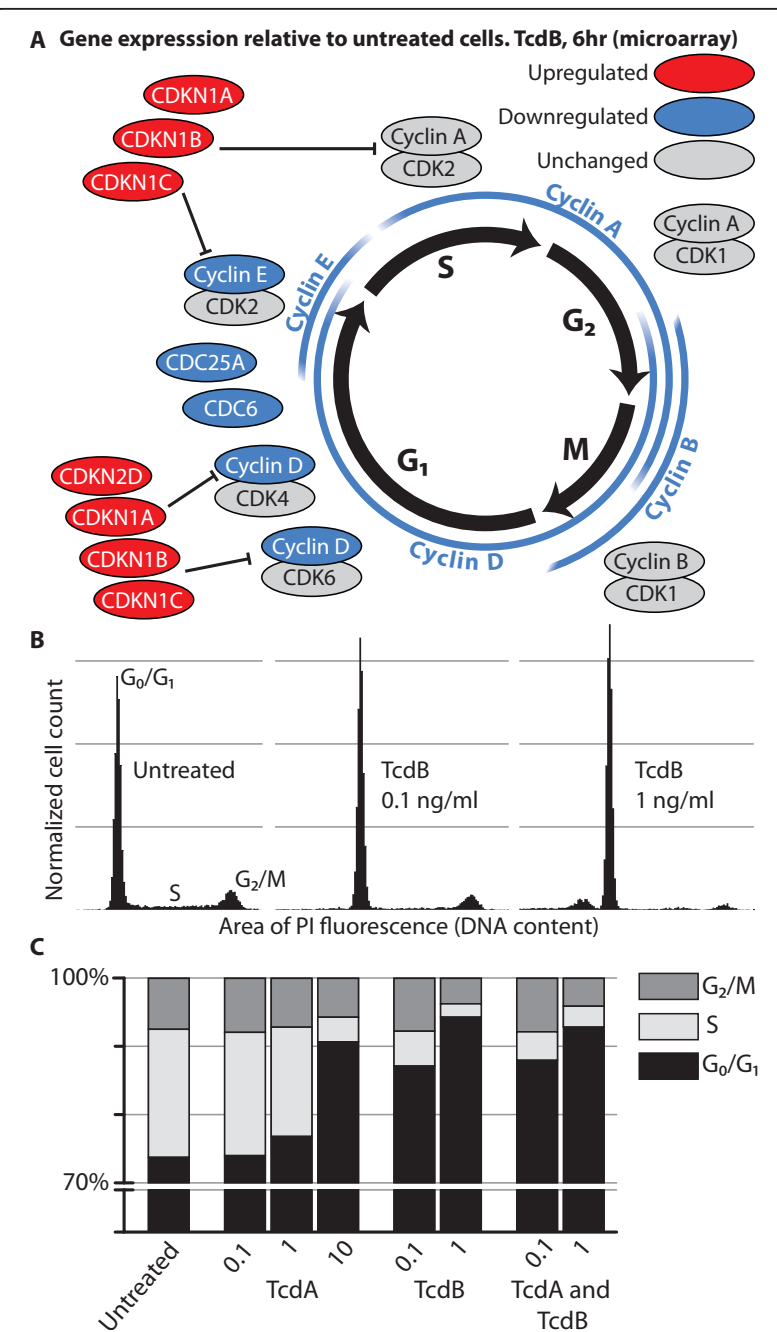

Figure 3 The altered gene expression of $G_{1}$ phase cell cycle regulators at $6 \mathrm{~h}$ and changes in the distribution of cells within the cell cycle. A. A schematic of cell cycle regulation with proteins placed next to the phase of cell cycle with which they are associated (p19 and p21 are the products of the CDKN2D and CDKN1A genes, respectively). Gray, blue, and red indicate genes with unchanged, increased, or decreased expression, respectively, post toxin treatment. B. Cells in a subconfluent culture were treated with the indicated concentrations of toxin for $24 \mathrm{~h}$. The DNA content of cells in each condition was quantified by PI fluorescence. The histograms of the area of PI fluorescence are normalized to the total number of cells (denoted as normalized cell count) in the sample such that the area under each histogram is equal to 1. In this way, the proportions of cells in each phase of the cell cycle may be compared for different size samples. The scale of the vertical axis is the same in each histogram. C. The percentage of cells in each phase of the cell cycle was calculated using ModFit LT software. Sub- $G_{0} / G_{1}$ cells were not included in the calculations.

morphology of cells treated for $24 \mathrm{hr}$ with higher concentrations of TcdA (100 ng/ml) and TcdB (10 and 100 $\mathrm{ng} / \mathrm{ml})$.

Our analysis of single-cell images from toxin-treated cultures reveals two unanticipated observations: (1) a biphasic distribution of apoptotic cells with respect to stage of cell cycle and (2) two populations of cells at the $\mathrm{G}_{2} / \mathrm{M}$ interface. Cells with a high-contrast bright-field image and a low area of PI fluorescence are classified as apoptotic (Figure 4A). Typically, apoptotic cells are associated with a PI fluorescence level less than that of the $G_{0} / G_{1}$ population. Here, a significant portion of the toxin-treated cells between the $G_{0} / G_{1}$ and $G_{2} / M$ cell populations (typically associated with/attributed to the S-phase) are apoptotic (Figure 4B). Thus, the accumulation of toxin-treated cells with S-phase levels of PIfluorescence is not the result of progression from $G_{1}$

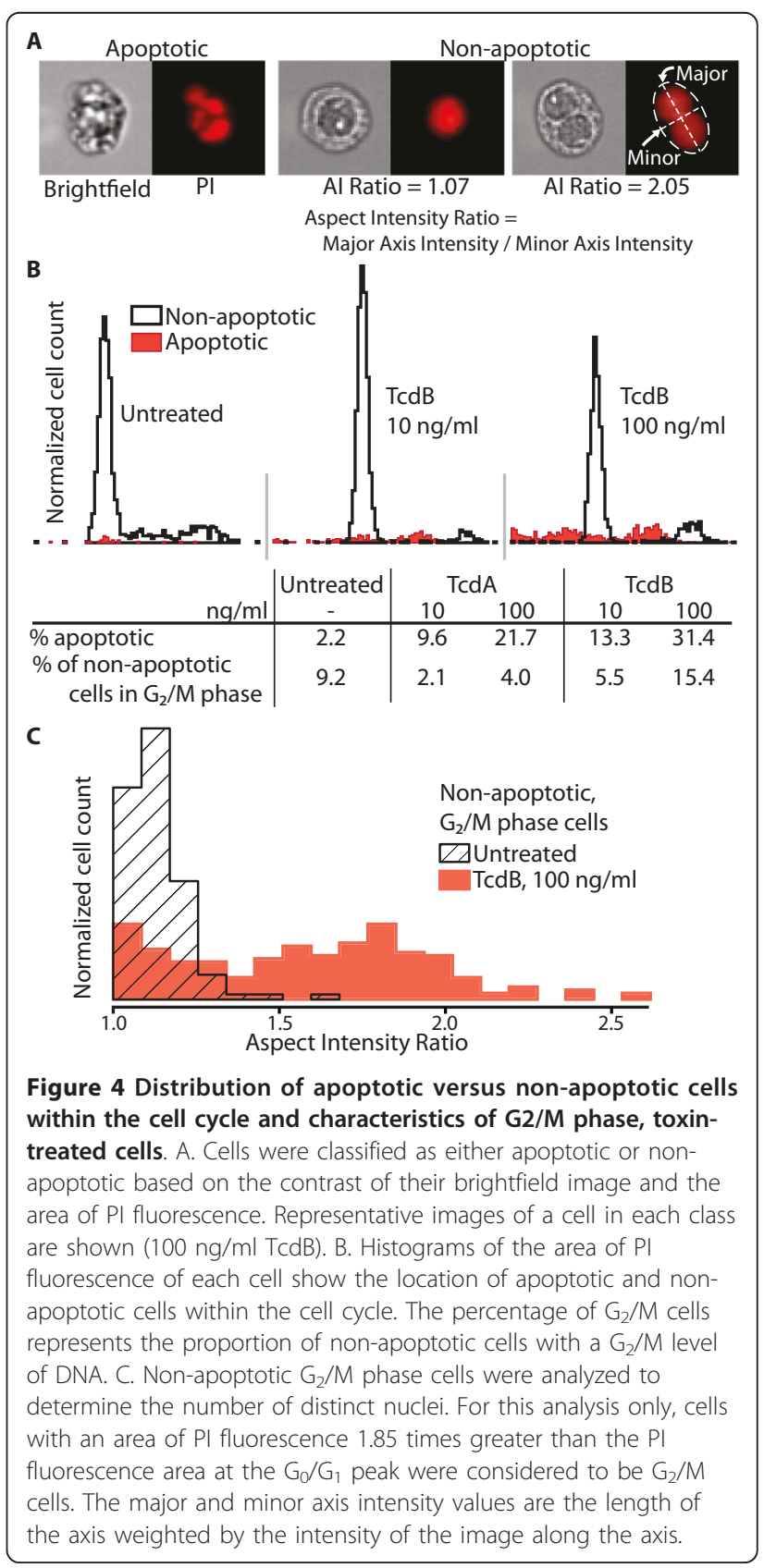


but rather the apoptosis of $\mathrm{G}_{2} / \mathrm{M}$ cells. Even $24 \mathrm{hr}$ after the addition of $100 \mathrm{ng} / \mathrm{ml}$ of $\mathrm{TcdB}$, apoptosis does not dominate or override effects on cell cycle. At the highest concentration tested $(100 \mathrm{ng} / \mathrm{ml}), 68.6 \%$ of TcdB-treated cells are still classified as non-apoptotic (Figure 4B). Of the total number of non-apoptotic cells, the proportion in the $G_{2} / M$ phase increases as the concentrations of either TcdA or TcdB increases, indicating an inhibition of progression from $G_{2} / M$ phase, in addition to the $G_{1}$ $\mathrm{S}$ block discussed above.

In order to understand the differences between toxintreated and control cells in $\mathrm{G}_{2} / \mathrm{M}$, we determined several cellular characteristics (circumference, area, and others) of individual cells using an imaging flow cytometer. The feature that best distinguishes toxin-treated from untreated cells is the intensity-weighted aspect ratio of the PI fluorescence image. When an ellipse is fit around the image, an aspect ratio near one indicates a circular nucleus and a higher aspect ratio indicates an elliptical nucleus or multiple nuclei (Figure 4A). Upon visual inspection, a high aspect ratio is due typically to binucleation. The higher proportion of binucleated cells in toxin-treated cells (Figure $4 \mathrm{C}$ ) indicates that the $\mathrm{G}_{2}$ / $\mathrm{M}$ block is attributable to a failure to complete cytokinesis [40]. Therefore, in addition to demonstration of a $\mathrm{G}_{1}$-S block, our results show an inhibition of progression at the $G_{2}-M$ transition, which is congruent with previous findings [15-18] in other cell types treated with different toxin concentrations. Importantly, these $G_{2} / M$ effects were observed at the same concentration of toxin used for microarray analysis $(100 \mathrm{ng} / \mathrm{ml})$. Again, TcdA elicited a similar response to $\mathrm{TcdB}$ at the same concentration, yet to a lesser extent, thus showing consistency from gene and protein expression to cell function.

\section{Discussion}

Understanding the differences between these two toxins is particularly relevant in determining their roles in $C$. difficile infection. Toxin A appears to be the dominant virulence factor in animal studies, yet Toxin B has higher enzymatic activity in vitro and is more potent when injected into Don cells and for human cells studied in vitro [26,41]. In a hamster model, Kuehne et al. found that strains of $C$. difficile producing only TcdA or $\mathrm{TcdB}$ are comparable in their virulence, while Lyras et al used a TcdA mutant to show that TcdB was the key virulence factor $[42,43]$. In this study, we used a systems approach to understand the effects of TcdA and TcdB on a human colonic epithelial cell line. We observed that the responses to these two toxins are strikingly similar, with the response to TcdB occurring more rapidly. Investigation of one of the biological consequences of these changes in gene expression revealed toxin effects at both the $\mathrm{G}_{1}-\mathrm{S}$ and the $\mathrm{G}_{2}-\mathrm{M}$ transitions.
In order to explore the interactions between $C$. difficile and intestinal epithelial cells, Janvilisri et al. examined the transcriptional responses of Caco- 2 cells and $C$. difficile organisms during an in vitro infection [44]. Because expression was measured at no more than $2 \mathrm{hr}$ post-infection, most of the changes in gene expression were slight, yet they identified functions such as cell metabolism and transport associated with affected genes. We focused on cells treated with TcdA or TcdB at a concentration and time course in which the cell morphology is strongly affected. The effects of TcdA and $\mathrm{T} \mathrm{cdB}$ on gene expression in host cells have been interrogated in other studies focusing on individual pathways, but until now, an analysis of the comprehensive global transcriptional response induced by either TcdA or TcdB alone had not been performed.

Our systems approach identified a disruption of the cell cycle not readily apparent from a ranked list of genes. This approach overcame difficulties in deciphering the particular relevance of genes known to be induced by several stimuli or genes whose expression leads to many possible cellular phenotypes. JUN is overall the most differentially expressed gene in our data, and, considering TcdA or TcdB as a cellular stress, its dramatic increase in expression is consistent with it being characterized as a stress-response gene. However, increased JUN expression has also been associated with the promotion of $G_{1}$ progression, protection from apoptosis after ultraviolet radiation, and even induction of apoptosis [45]. Clearly, multiple events may lead to the same changes in expression of an individual gene. The identification of functions associated with many of the differentially expressed genes thus provides better evidence of actual biological functions important to the toxin response.

These results have clarified the effects of TcdA and $\mathrm{TcdB}$ at each stage of the cell cycle. In studying Rho signaling, Welsh et al. showed that combined Rho, Rac, and Cdc42 inhibition by TcdA $(200 \mathrm{ng} / \mathrm{ml})$ in fibroblasts led to decreased cyclin D1 expression and an inability of serum-starved cells, stimulated with fetal calf serum and treated with toxin, to progress past the $G_{1}$ phase [46]. Importantly, we show that a strong $G_{1}$ arrest occurs in unsynchronized, proliferating epithelial cells. Only when treated with higher concentrations $(100 \mathrm{ng} / \mathrm{ml} \mathrm{TcdA}, 10$ $\mathrm{ng} / \mathrm{ml} \mathrm{TcdB}$ ) of toxin did we begin to observe the inhibition of cell division at the $G_{2} / M$ phase in a significant proportion of cells. With regard to cell death, others have shown an increased susceptibility of S-phase cells to toxin treatment [47]. We did observe an increase in the proportion of apoptotic $S$ or $\mathrm{G}_{2} / \mathrm{M}$ phase cells. At low concentrations (10 ng/ml TcdA, $1 \mathrm{ng} / \mathrm{ml} \mathrm{TcdB}$ ), the decrease in the proportion of S-phase cells, however, could not be entirely accounted for by death of cells at 
a particular point in the growth cycle. Rather, many non-apoptotic cells remained in the $G_{0} / G_{1}$ phase.

\section{Conclusion}

Our results have several implications in reference to the role of these toxins in pathogenicity. In a host, the gut epithelial cells normally turn over every 2-3 days [48]. Disruption of this cellular renewal process, and therefore cell cycle, impairs the maintenance of the epithelial barrier. The ability of both $\mathrm{TcdA}$ and TcdB to arrest growth at the $G_{0} / G_{1}$ phase and the $G_{2}-M$ transition, by likely different mechanisms $\left(G_{1}\right.$ arrest occurs even at low toxin concentrations and is associated with altered protein signaling; $G_{2}$ arrest is likely associated with disorganization of the cytoskeleton), places each toxin in the category of cyclomodulins. As has been previously shown however, control of cell proliferation is certainly not their only or necessarily primary effect (e.g., inflammation, disruption of tight junctions). The high similarity in the gene expression induced by these two toxins indicates that, qualitatively, their effects and the overall cellular responses are comparable. The rate of internalization and/or the rapidity of inactivation of Rho-family proteins in different hosts may partially account for the different rates in the onset of gene expression. Though we did not observe synergy or antagonism between the two toxins, it is possible that each could differentially bind various cell types and therefore act synergistically within a host. Clearly, the response to each toxin is a complex process involving the activation and inhibition of several pathways in different cell types. The integration and use of the data we present here have and will continue to aid the organization of these multiple effects into a central framework for interrogating toxin activity.

\section{Additional material}

Additional file 1: Supplementary Methods. Materials and methods for western blotting and qRT-PCR.

Additional file 2: Figure S1. qRT-PCR validation of microarray and gene expression of highly differentially expressed genes.

Additional file 3: Figure S2. Enriched GO categories within the Cellular Component and Biological Process ontologies.

Additional file 4: Figure S3. Gene expression from toxin-treated cells in subconfluent and confluent cultures and protein expression after treatment with various toxin concentrations.

\footnotetext{
Acknowledgements

The authors are grateful to David Lyerly, Ph.D., and TechLab, Inc., Blacksburg, $V A$, for the generous gift of Toxins $A$ and $B$.

Funding

This work was supported by the National Institute of Allergy and Infectious Diseases Regional Center of Excellence program through the Mid-Atlantic Regional Center of Excellence in Biodefense and Emerging Infections [5U54 Al057168]. KMD is a trainee on the Infectious Diseases Training Grant to the
}

University of Virginia Division of Infectious Diseases and International Health [5T32 Al007046].

\section{Author details}

'Department of Biomedical Engineering, University of Virginia, Charlottesville, Virginia, 22908, USA. ${ }^{2}$ Division of Infectious Diseases and International Health, Department of Medicine, University of Virginia, Charlottesville, Virginia, 22908, USA. ${ }^{3}$ Department of Microbiology, University of Virginia, Charlottesville, Virginia, 22908, USA.

\section{Authors' contributions}

KMD performed all computational and statistical analyses, cell-cycle experiments, image processing, and drafted the manuscript. GMD performed all experiments for obtaining mRNA for microarrays and PCR. MCG, KMD, and LMC performed experiments to measure protein expression and quantify cell-cycle effects. MDS and JAL performed and contributed to the design of the flow and image cytometry experiments. All authors together conceived this study, participated in its design and coordination, and helped to draft the manuscript. All authors read and approved of the final manuscript.

Received: 16 November 2011 Accepted: 6 January 2012

Published: 6 January 2012

\section{References}

1. Freeman J, Bauer MP, Baines SD, Corver J, Fawley WN, Goorhuis B, Kuijper EJ, Wilcox MH: The changing epidemiology of Clostridium difficile infections. Clin Microbiol Rev 2010, 23(3):529-549.

2. Warny M, Pepin J, Fang A, Killgore G, Thompson A, Brazier J, Frost E, MCDonald LC: Toxin production by an emerging strain of Clostridium difficile associated with outbreaks of severe disease in North America and Europe. Lancet 2005, 366(9491):1079-1084.

3. Zilberberg MD, Shorr AF, Kollef MH: Increase in adult Clostridium difficilerelated hospitalizations and case-fatality rate, United States, 2000-2005. Emerg Infect Dis 2008, 14(6):929-931.

4. Dubberke ER, Wertheimer Al: Review of current literature on the economic burden of Clostridium difficile infection. Infect Control Hosp Epidemiol 2009, 30(1):57-66

5. Frisch C, Gerhard R, Aktories K, Hofmann F, Just I: The complete receptorbinding domain of Clostridium difficile toxin $A$ is required for endocytosis. Biochem Biophys Res Commun 2003, 300(3):706-711.

6. Papatheodorou P, Zamboglou C, Genisyuerek S, Guttenberg G, Aktories K: Clostridial glucosylating toxins enter cells via clathrin-mediated endocytosis. PLoS One 2010, 5(5):e10673.

7. Egerer M, Giesemann T, Jank T, Satchell KJ, Aktories K: Auto-catalytic cleavage of Clostridium difficile toxins $A$ and $B$ depends on cysteine protease activity. J Biol Chem 2007, 282(35):25314-25321.

8. Nusrat $A$, von Eichel-Streiber $C$, Turner JR, Verkade $P$, Madara $J$, Parkos CA: Clostridium difficile toxins disrupt epithelial barrier function by altering membrane microdomain localization of tight junction proteins. Infect Immun 2001, 69(3):1329-1336.

9. Tompkins WA, Watrach AM, Schmale JD, Schultz RM, Harris JA: Cultural and antigenic properties of newly established cell strains derived from adenocarcinomas of the human colon and rectum. J Natl Cancer Inst 1974, 52(4):1101-1110.

10. Comer JE, Galindo CL, Chopra AK, Peterson JW: GeneChip analyses of global transcriptional responses of murine macrophages to the lethal toxin of Bacillus anthracis. Infect Immun 2005, 73(3):1879-1885.

11. Comer JE, Galindo CL, Zhang F, Wenglikowski AM, Bush KL, Garner HR, Peterson JW, Chopra AK: Murine macrophage transcriptional and functional responses to Bacillus anthracis edema toxin. Microb Pathog 2006, 41:(2-3):96-110.

12. Lu C, Pelech S, Zhang H, Bond J, Spach K, Noubade R, Blankenhorn EP, Teuscher $C$ : Pertussis toxin induces angiogenesis in brain microvascular endothelial cells. J Neurosci Res 2008, 86(12):2624-2640.

13. Leyva-Illades D, Cherla RP, Galindo CL, Chopra AK, Tesh VL: Global transcriptional response of macrophage-like THP-1 cells to Shiga toxin type 1. Infect Immun 2010, 78(6):2454-2465.

14. Nougayrede JP, Taieb F, De Rycke J, Oswald E: Cyclomodulins: bacterial effectors that modulate the eukaryotic cell cycle. Trends Microbiol 2005, 13(3):103-110. 
15. Fiorentini C, Fabbri A, Falzano L, Fattorossi A, Matarrese P, Rivabene R, Donelli $\mathrm{G}$ : Clostridium difficile toxin $\mathrm{B}$ induces apoptosis in intestinal cultured cells. Infect Immun 1998, 66(6):2660-2665.

16. Kim H, Kokkotou E, Na X, Rhee SH, Moyer MP, Pothoulakis C, Lamont JT: Clostridium difficile toxin A-induced colonocyte apoptosis involves p53dependent p21(WAF1/CIP1) induction via p38 mitogen-activated protein kinase. Gastroenterology 2005, 129(6):1875-1888.

17. Gerhard R, Nottrott S, Schoentaube J, Tatge H, Olling A, Just I: Glucosylation of Rho GTPases by Clostridium difficile toxin A triggers apoptosis in intestinal epithelial cells. J Med Microbiol 2008, 57(Pt 6):765-770.

18. Nottrott S, Schoentaube J, Genth H, Just I, Gerhard R: Clostridium difficile toxin A-induced apoptosis is p53-independent but depends on glucosylation of Rho GTPases. Apoptosis 2007, 12(8):1443-1453.

19. Wu ZJ, Irizarry RA, Gentleman R, Martinez-Murillo F, Spencer F: A modelbased background adjustment for oligonucleotide expression arrays. J Am Stat Assoc 2004, 99(468):909-917.

20. Smyth GK: Linear models and empirical bayes methods for assessing differential expression in microarray experiments. Stat Appl Genet Mol Biol 2004, 3:Article3.

21. Smyth GK: Limma: linear models for microarray data. In Bioinformatics and Computational Biology Solutions using $R$ and Bioconductor. Edited by: Gentleman R, Carey V, Dudoit S, Irizarry R, Huber W. Springer, New York; 2005:397-420, edn.

22. Barrell D, Dimmer E, Huntley RP, Binns D, O'Donovan C, Apweiler R: The GOA database in 2009-an integrated Gene Ontology Annotation resource. Nucleic Acids Res 2009, , 37 Database: D396-403.

23. Alexa A, Rahnenfuhrer J, Lengauer T: Improved scoring of functional groups from gene expression data by decorrelating GO graph structure. Bioinformatics 2006, 22(13):1600-1607.

24. George TC, Basiji DA, Hall BE, Lynch DH, Ortyn WE, Perry DJ, Seo MJ, Zimmerman CA, Morrissey PJ: Distinguishing modes of cell death using the ImageStream multispectral imaging flow cytometer. Cytometry $A$ 2004, 59(2):237-245.

25. Henery S, George T, Hall B, Basiji D, Ortyn W, Morrissey P: Quantitative image based apoptotic index measurement using multispectral imaging flow cytometry: a comparison with standard photometric methods. Apoptosis 2008, 13(8):1054-1063.

26. Chaves-Olarte E, Weidmann M, Eichel-Streiber C, Thelestam M: Toxins A and $B$ from Clostridium difficile differ with respect to enzymatic potencies, cellular substrate specificities, and surface binding to cultured cells. J Clin Invest 1997, 100(7):1734-1741.

27. Qa'Dan M, Ramsey M, Daniel J, Spyres LM, Safiejko-Mroczka B, OrtizLeduc W, Ballard JD: Clostridium difficile toxin B activates dual caspasedependent and caspase-independent apoptosis in intoxicated cells. Cell Microbiol 2002, 4(7):425-434.

28. Carneiro BA, Fujii J, Brito GA, Alcantara C, Oria RB, Lima AA, Obrig T, Guerrant RL: Caspase and bid involvement in Clostridium difficile toxin A-induced apoptosis and modulation of toxin A effects by glutamine and alanyl-glutamine in vivo and in vitro. Infect Immun 2006, 74(1):81-87.

29. Brito GA, Fujji J, Carneiro-Filho BA, Lima AA, Obrig T, Guerrant RL: Mechanism of Clostridium difficile toxin A-induced apoptosis in T84 cells. J Infect Dis 2002, 186(10):1438-1447.

30. Matarrese P, Falzano L, Fabbri A, Gambardella L, Frank C, Geny B, Popoff MR, Malorni W, Fiorentini C: Clostridium difficile toxin B causes apoptosis in epithelial cells by thrilling mitochondria. Involvement of ATP-sensitive mitochondrial potassium channels. J Biol Chem 2007, 282(12):9029-9041.

31. He D, Hagen SJ, Pothoulakis C, Chen M, Medina ND, Warny M, LaMont JT: Clostridium difficile toxin A causes early damage to mitochondria in cultured cells. Gastroenterology 2000, 119(1):139-150.

32. He D, Sougioultzis S, Hagen S, Liu J, Keates S, Keates AC, Pothoulakis C, Lamont JT: Clostridium difficile toxin A triggers human colonocyte IL-8 release via mitochondrial oxygen radical generation. Gastroenterology 2002, 122(4):1048-1057.

33. Qiu B, Pothoulakis C, Castagliuolo I, Nikulasson S, LaMont JT: Participation of reactive oxygen metabolites in Clostridium difficile toxin A-induced enteritis in rats. Am J Physiol 1999, 276(2 Pt 1):G485-490.

34. Flegel WA, Muller F, Daubener W, Fischer HG, Hadding U, Northoff H: Cytokine response by human monocytes to Clostridium difficile toxin A and toxin B. Infect Immun 1991, 59(10):3659-3666.
35. Meyer GK, Neetz A, Brandes G, Tsikas D, Butterfield JH, Just I, Gerhard R: Clostridium difficile toxins $A$ and $B$ directly stimulate human mast cells. Infect Immun 2007, 75(8):3868-3876.

36. Lee JY, Park HR, Oh YK, Kim YJ, Youn J, Han JS, Kim JM: Effects of transcription factor activator protein-1 on interleukin-8 expression and enteritis in response to Clostridium difficile toxin A. J Mol Med 2007, 85(12):1393-1404.

37. Na X, Zhao D, Koon HW, Kim H, Husmark J, Moyer MP, Pothoulakis C, LaMont JT: Clostridium difficile toxin B activates the EGF receptor and the ERK/MAP kinase pathway in human colonocytes. Gastroenterology 2005, 128(4):1002-1011.

38. Murray AW: Recycling the cell cycle: cyclins revisited. Cell 2004, 116(2):221-234.

39. Denicourt C, Dowdy SF: Cip/Kip proteins: more than just CDKs inhibitors. Genes Dev 2004, 18(8):851-855.

40. Huelsenbeck SC, May M, Schmidt G, Genth H: Inhibition of cytokinesis by Clostridium difficile toxin $B$ and cytotoxic necrotizing factors-reinforcing the critical role of RhoA in cytokinesis. Cell Motil Cytoskeleton 2009, 66(11):967-975.

41. Riegler M, Sedivy R, Pothoulakis C, Hamilton G, Zacherl J, Bischof G, Cosentini E, Feil W, Schiessel R, LaMont JT, et al: Clostridium difficile toxin $B$ is more potent than toxin $A$ in damaging human colonic epithelium in vitro. J Clin Invest 1995, 95(5):2004-2011.

42. Kuehne SA, Cartman ST, Heap JT, Kelly ML, Cockayne A, Minton NP: The role of toxin A and toxin B in Clostridium difficile infection. Nature 2010.

43. Lyras D, O'Connor JR, Howarth PM, Sambol SP, Carter GP, Phumoonna T, Poon R, Adams V, Vedantam G, Johnson S, et al: Toxin B is essential for virulence of Clostridium difficile. Nature 2009, 458(7242):1176-1179.

44. Janvilisri T, Scaria J, Chang YF: Transcriptional profiling of Clostridium difficile and Caco-2 cells during infection. J Infect Dis 2010, 202(2):282-290.

45. Ameyar M, Wisniewska M, Weitzman JB: A role for AP-1 in apoptosis: the case for and against. Biochimie 2003, 85(8):747-752.

46. Welsh CF, Roovers K, Villanueva J, Liu Y, Schwartz MA, Assoian RK: Timing of cyclin D1 expression within G1 phase is controlled by Rho. Nat Cell Biol 2001, 3(11):950-957.

47. Huelsenbeck J, Dreger S, Gerhard R, Barth H, Just I, Genth H: Difference in the cytotoxic effects of toxin B from Clostridium difficile strain VPI 10463 and toxin B from variant Clostridium difficile strain 1470. Infect Immun 2007, 75(2):801-809.

48. Kim M, Ashida H, Ogawa M, Yoshikawa Y, Mimuro H, Sasakawa C: Bacterial interactions with the host epithelium. Cell Host Microbe 2010, 8(1):20-35.

49. Resnik P: Semantic similarity in a taxonomy: An information-based measure and its application to problems of ambiguity in natural language. J Artif Intell Res 1999, 11:95-130.

doi:10.1186/1752-0509-6-2

Cite this article as: D'Auria et al:: Systems analysis of the transcriptional response of human ileocecal epithelial cells to Clostridium difficile toxins and effects on cell cycle control. BMC Systems Biology 2012 6:2.

\section{Submit your next manuscript to BioMed Central and take full advantage of:}

- Convenient online submission

- Thorough peer review

- No space constraints or color figure charges

- Immediate publication on acceptance

- Inclusion in PubMed, CAS, Scopus and Google Scholar

- Research which is freely available for redistribution

Submit your manuscript at www.biomedcentral.com/submit
C Biomed Central 